\title{
WS1
}

\section{Technologies for Seismic Data Processing}

\author{
S.V. Volferts* (Schlumberger)
}

\section{SUMMARY}

Over the last 50-60 years technologies of seismic data processing stepped far forward. The level of development of computer technology today allows to implement complex algorithms in real production deadlines. The WesternGeco commitment to research and development ensures the Omega system benefits from the latest geophysical processing technology. Advanced algorithms are available including 3D GSMP general surface multiple prediction, XIMP Extended internal Multiple Prediction and others.

Most recently, the depth migration technologies were used not so often and only in cases when it was required by structurally complex geology. Now more projects are carried out depth processing, due to both a high-tech possibilities, and understanding of depth migration is needed to improve the quality of processing, regardless complexity of survey. Except standard migration algorithms advanced technologies of RTM migration, Adaptive Beam migration and Gaussian Packet migration are available in Omega. Omega Integration integrates the algorithm power of Omega with the Petrel software visualization canvas, providing new, powerful geophysical workflows. 
Over the last 50-60 years technologies of seismic data processing stepped far forward. The level of development of computer technology today allows to implement complex algorithms in real production deadlines. The WesternGeco commitment to research and development ensures the Omega system benefits from the latest geophysical processing technology. Advanced algorithms are available including 3D GSMP general surface multiple prediction, XIMP Extended internal Multiple Prediction and others.

Most recently, the depth migration technologies were used not so often and only in cases when it was required by structurally complex geology. Now more projects are carried out depth processing, due to both a high-tech possibilities, and understanding of depth migration is needed to improve the quality of processing, regardless complexity of survey. Except standard migration algorithms advanced technologies of RTM migration, Adaptive Beam migration and Gaussian Packet migration are available in Omega. Omega Integration integrates the algorithm power of Omega with the Petrel software visualization canvas, providing new, powerful geophysical workflows.

\section{Технологии обработки сейсморазведочных данных}

Стратегия компании WesternGeco, направленная на углубленные научные исследования и разработки, привела к созданию обновленного программного комплекса Omega, оснащенного самыми современными технологиями в области обработки сейсморазведочных данных. К их числу относятся: обобщенное предсказание поверхностно-обусловленных кратных волн 3D GSMP, прогноз кратных волн в слое ХІМР и другие.

Совсем недавно примеры использования технологии глубинной миграции были редкостью и были обусловлены, в основном, сложным структурным строением исследуемых площадей. Сейчас все больше проектов выполняется по глубинному графу, благодаря как современным техническим возможностям, так и пониманию необходимости выполнения глубинной миграции для повышения качества обработки независимо от сложности разреза. Программный комплекс Omega имеет в своем арсенале, кроме стандартной глубинной миграции до суммирования, такие современные передовые технологии, как RTM миграция в обращенном времени, ABEAM миграция адаптивными лучами и гауссовский пакет миграции.

Кроме того, интеграция систем Omega и Petrel позволяет объединить алгоритмы Omega и широкие возможности визуализации Petrel, обеспечивая связь обработки и интерпретации сейсмических данных и открывая новые перспективы для решения геофизических задач. 